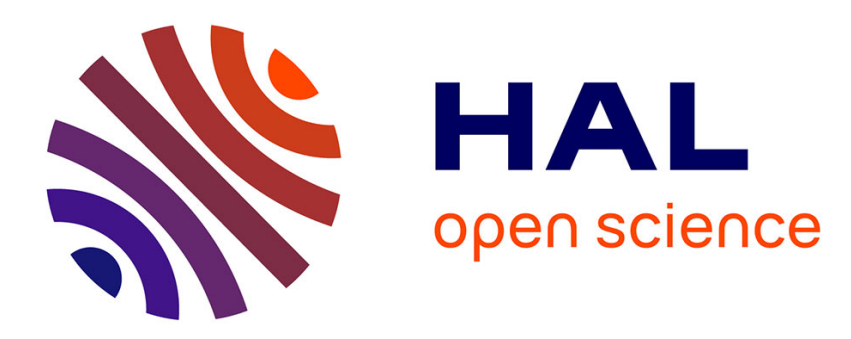

\title{
PCDH19-related infantile epileptic encephalopathy: an unusual X-linked inheritance disorder.
}

Christel Depienne, Eric Leguern

\section{To cite this version:}

Christel Depienne, Eric Leguern. PCDH19-related infantile epileptic encephalopathy: an unusual X-linked inheritance disorder.. Human Mutation, 2012, 33 (4), pp.627-34. 10.1002/humu.22029 . inserm-00669941

\section{HAL Id: inserm-00669941 https://www.hal.inserm.fr/inserm-00669941}

Submitted on 3 Oct 2014

HAL is a multi-disciplinary open access archive for the deposit and dissemination of scientific research documents, whether they are published or not. The documents may come from teaching and research institutions in France or abroad, or from public or private research centers.
L'archive ouverte pluridisciplinaire HAL, est destinée au dépôt et à la diffusion de documents scientifiques de niveau recherche, publiés ou non, émanant des établissements d'enseignement et de recherche français ou étrangers, des laboratoires publics ou privés. 
PCDH19-related Infantile Epileptic Encephalopathy: An Unusual X-linked Inheritance Disorder

Christel Depienne ${ }^{1,2,3}$ and Eric LeGuern ${ }^{1,2,3}$

${ }^{1}$ INSERM, CRICM (UMRS_975), Hôpital de la Pitié-Salpêtrière, F-75013, Paris, France;

${ }^{2}$ AP-HP, Département de Génétique et Cytogénétique, Centre de Génétique Moléculaire et Chromosomique, Hôpital de la Pitié-Salpêtrière, F-75013, Paris, France;

${ }^{3}$ UPMC, Université Paris 06, F-75005, Paris, France. 


\begin{abstract}
PCDH19 encodes protocadherin 19 on chromosome Xq22.3. This 1148 amino-acid protein, highly expressed during brain development, could play significant roles in neuronal migration or establishment of synaptic connections. $\mathrm{PCDH} 19$ is composed of 6 exons, with a large first exon encoding the entire extracellular domain of the protein. Heterozygous $P C D H 19$ mutations were initially identified in epilepsy and mental retardation limited to females, a familial disorder with a singular mode of inheritance since only heterozygous females are affected whereas hemizygous males are asymptomatic. Yet, mosaic males can also be affected, supporting cellular interference as the pathogenic mechanism. Recently, mutations in PCDH19, mostly occurring de novo, were shown to be a frequent cause of sporadic infantile-onset epileptic encephalopathy in females. PCDH19 mutations were also identified in epileptic females without cognitive impairment. Typical features of this new epileptic syndrome include generalized or focal seizures highly sensitive to fever, and brief seizures occurring in clusters, repeating during several days. Here we present a review of the published mutations in the PCDH19 gene to date and report on new mutations. $P C D H 19$ has become the second most relevant gene in epilepsy after SCN1A.
\end{abstract}

KEY WORDS: PCDH19, Epilepsy, X-linked, females, male sparing, cellular interference 


\section{INTRODUCTION}

Mutations in PCDH19 (MIM\# 300460) were originally identified in 2008 in rare large families in which female patients had variable degrees of epilepsy and intellectual deficits. This disorder, first reported as epilepsy and mental retardation limited to females (or epilepsy, femalerestricted, with mental retardation, EFMR) and recently renamed Epileptic encephalopathy, early infantile, 9 (MIM\# 300088), was transmitted via asymptomatic males, suggesting an unusual Xlinked inheritance with selective involvement of females [Juberg and Hellman, 1971; Fabisiak and Erickson, 1990; Ryan et al., 1997; Dibbens et al., 2008].

Recently, $P C D H 19$-related infantile epileptic encephalopathy turned out to be more frequent than first anticipated on the observation of families, PCDH19 becoming the second most clinically relevant gene in epilepsy after SCN1A (MIM\# 182389). Most patients with PCDH19 mutations are sporadic cases or belong to families with few affected female patients, making the recognition of the inheritance pattern difficult. In addition, associated clinical features, including age at onset, seizure types and severity, and the degree of cognitive disability, are highly variable. However, clinical characteristics such as clustering of repeated seizures within short periods of time are now emerging as hallmark features that orient etiological diagnosis towards PCDH19. This mutation update summarizes the mutations identified in the gene and the recent findings in the field. 


\section{Background}

Protocadherins (pcdhs) are transmembrane proteins primarily involved in calcium-dependent adhesion that constitute the largest subgroup of the cadherin superfamily. Mammalian genomes contain more than $70 \mathrm{Pcdh}$ genes that are divided into two groups based on their genomic structure: clustered ( $\sim 58$ genes, $P c d h \alpha, \beta, \gamma)$ and non-clustered $P c d h$ genes ( $\sim 13$ genes, Pcdh $\delta$ and other Pcdhs). Pcdhs typically have six or more extracellular calcium-binding cadherin repeats or ectodomains (EC domains), which are required for cell-cell homophilic or heterophilic interactions, and a divergent cytoplasmic domain [Yagi and Takeichi, 2000; Patel et al., 2003; Redies et al., 2005; Patel et al., 2006; Morishita and Yagi, 2007]. Protocadherins, like many other cadherins, are predominantly expressed in the brain, where they play significant roles in neurodevelopment, such as neuronal migration and synaptic plasticity [Frank and Kemler, 2002; Junghans et al., 2005; Redies et al., 2005; Morishita and Yagi, 2007]. The combinatorial expression of multiple cadherin and protocadherin genes could contribute to the molecular specification of the vast complexity of neurons in the cerebral cortex [Krishna et al., 2011].

PCDH19 (MIM\# 300460), located on chromosome Xq22.3, encodes the 1148 amino acid protocadherin 19 , and belongs to the $\delta 2$-subclass of non-clustered protocadherins that also includes PCDH8, PCDH10, PCDH17 and PCDH18 [Wolverton and Lalande, 2001; Redies et al., 2005]. The PCDH19 gene has six coding exons, the first exon being unusually large and encoding the entire extracellular domain, composed of six EC domains (Fig. 1, based on the NM_001184880.1 reference transcript corresponding to the longest isoform). PCDH19 expression is spatially and temporally regulated in the central nervous system during mammalian 
development and shows a unique expression profile among protocadherins. In particular, protocadherin 19 is highly expressed in the developing brain, including the subventricular zone, the intermediate zone, the subplate, specific layers (layers II, IV, V and VI) of the cerebral cortex, the hippocampus and the subiculum [Vanhalst et al., 2005; Gaitan and Bouchard, 2006; Kim et al., 2007; Krishna et al., 2009; Kim et al., 2010; Hertel and Redies, 2011; Krishna et al., 2011]. Two other isoforms (NM_020766.1 and NM_001105243.1) resulting from the alternative splicing of exon 2 and the existence of two possible acceptor sites for intron 4 (adding a residue at the beginning of exon 5) exist in databases but their existence, distribution and respective roles need to be confirmed and studied at the molecular level.

The precise function of protocadherin 19 remains currently unknown. Yet, other $\delta 2-$ protocadherins were reported to mediate calcium-dependent cell-cell adhesion in vitro and cell sorting in vivo [Redies et al., 2005] and could regulate the establishment of neuronal connections during brain development and/or remodeling of selective synaptic connections during the early postnatal stage [Kim et al., 2007]. However, in contrast to cadherins, which associate through strong homophilic interactions, the extracellular domain of $\mathrm{PCDH} 19$ exhibits specific but weak homophilic adhesive properties, suggesting that the involvement of $P C D H 19$ in cell adhesion could involve heterophilic interactions [Biswas et al., 2010; Tai et al., 2010].

\section{Variants}

\section{Pathogenic Mutations}

More than 60 different mutations in PCDH19 have been identified (Table 1A and Fig. 1). All types of DNA alterations are observed, including nonsense mutations, small nucleotide deletions and insertions, mutations altering the splice sites, missense mutations, and intragenic or whole 
gene deletions. Half of the pathologic allelic variants result in the appearance of premature termination codons, either due to nonsense mutations (18.3\%; 17/93 patients, based on review of the literature and personal data), small deletions or insertions leading to a frameshift $(25.8 \%$, 24/93) or splice site mutations $(3.2 \%, 3 / 93)$. These mutation types are scattered along the PCDH19 gene with the exception of exon 2, in which no variants or mutations have been reported so far. Whole gene or intragenic deletions have been reported in only 6 patients $(6.5 \%$, 6/93) [Depienne et al., 2009; Depienne et al., 2011; Vincent et al., 2011] but this mutation class has likely been underestimated since most studies used only direct sequencing, which misses heterozygous deletions, to screen $P C D H 19$ (Table 1C). Missense substitutions, which represent 46.2\% (43/93) of the mutations are, contrary to other mutation types, all clustered in exon 1 , where they affect highly conserved amino acids in the large extracellular domain of protocadherin 19. Several recurrent mutations have been reported in patients, the most frequent being the Asn340Ser missense mutation (Table 1A).

Mutations have been reported in the Leiden Open Variation Database (X chromosome gene database, PCDH19: http://www.lovd.nl/PCDH19).

\section{Polymorphisms and variants of unknown significance}

The PCDH19 gene contains few known polymorphisms (Table 2). The most frequent natural variations reported correspond to synonymous substitutions located in exon 1. Rarer, nonpathogenic missense polymorphisms, all clustered in the intracellular domain of protocadherin 19 (exon 6), were occasionally found in patients and in ethnically matched control populations, suggesting that this domain, contrary to the extracellular domain, can tolerate some missense changes. One missense variant located in exon 3 has been identified in a patient with 
mental retardation but the pathogenic effect of this variant remains uncertain (Table 1B) [Tarpey et al., 2009].

\section{Biological Relevance}

\section{Mutations in PCDH19: a Loss of Function at the Cellular Level}

The mutation spectrum in $\mathrm{PCDH} 19$ is compatible with a loss of function of the mutated allele. Messenger RNAs with mutations introducing premature termination codons (PTC) have indeed been shown to be degraded via the nonsense-mediated mRNA decay (NMD) surveillance system of the cell in patients' fibroblasts [Dibbens et al., 2008]. The identification of whole gene deletions in three patients [Depienne et al., 2009; Depienne et al., 2011] also supports the notion that loss of function is the main consequence of the mutations. Missense mutations located in the extracellular domain could alter the adhesive properties of protocadherin 19 and also lead to a loss of function. In particular, the Asn340Ser and Glu414Gln mutations could specifically alter amino acids involved in calcium binding [Patel et al., 2006; Marini et al., 2010]. However, these hypotheses have yet to be formally tested.

\section{Cellular Interference: a Gain of Function at the Tissue Level}

Males with hemizygous $\mathrm{PCDH} 19$ mutations show normal cognitive function and do not have seizures, although a subtle psychiatric phenotype was evoked in some asymptomatic carriers [Dibbens et al., 2008]. The absence of major symptoms in hemizygous males indicates that the constitutive loss of function of protocadherin 19 (i.e., the absence of functional protein in all the cells of an individual's body) is not pathogenic. Hence, although protocadherin 19 could be essential for early brain morphogenesis in other species [Emond et al., 2009], it is a non essential 
protein in humans, its absence likely being compensated for or buffered by other proteins and pathways.

In contrast, females with heterozygous $P C D H 19$ mutations present with early intractable seizures and a variable degree of mental retardation. $\mathrm{PCDH} 19$ is located in a region submitted to $\mathrm{X}$ inactivation in females [Dibbens et al., 2008]. Random X-inactivation in mutated females is expected to lead to tissue mosaicism; i.e., co-existence of cells that have inactivated the mutated PCDH19 allele and express the normal protein, and PCDH19-negative cells that have inactivated the normal allele [Depienne et al., 2009]. This mosaicism could account for the pathogenesis by altering cell-cell interactions [Ryan et al., 1997; Dibbens et al., 2008; Depienne et al., 2009]. The loss of function of protocadherin 19 at the level of the cell would thus result in a gain of function at the tissue level because of abnormal interactions between "mutated" and "normal" cells. A mechanism of this type was termed "cellular interference" [Wieland et al., 2004] in reference to the "metabolic interference" concept developed many years ago by William Johnson [Johnson, 1980]. According to this theory, mosaic males would be affected like mutated females. The identification of an affected male with a mosaic $\mathrm{PCDH} 19$ deletion in his fibroblasts, strongly supports cellular interference as the pathogenic mechanism associated with $\mathrm{PCDH} 19$ mutations [Depienne et al., 2009]. To definitely establish that cellular interference is the pathogenic mechanism, it would however be necessary to demonstrate that females homozygous for PCDH19 mutations are also unaffected like hemizygous males. In the absence of human cases, the development of a PCDH19-deficient mouse model will be crucial to confirm this pathogenic mechanism, assuming that the pathogenic mechanisms are identical in both species.

Interestingly, another human disorder, craniofrontonasal syndrome (CFNS; MIM\# 304110), caused by mutations in EFNB1, the gene encoding Ephrin B1, a ligand for Eph receptors (EphR) 
on chromosome $\mathrm{Xq12}$, has the same unusual X-linked pattern of inheritance [Wieland et al., 2004]. Ephrin B1/EphR signaling plays a role in cell migration and pattern formation during developmental morphogenesis [Klein, 2004], reminiscent of the possible function of protocadherin 19 in brain development. Cellular interference has been confirmed as the pathogenic mechanism in CFNS. Female mice heterozygous for mutations in Ephrin B1 have a mosaic expression of Ephrin B1 resulting in ectopic interactions between the Ephrin B1 ligand and EphB receptors that are sufficient to induce the skeletal defects [Compagni et al., 2003].

\section{Clinical Relevance}

\section{Clinical Features of Patients with $\mathrm{PCDH} 19$ Mutations}

Female patients with heterozygous $\mathrm{PCDH} 19$ mutations have epileptic phenotypes ranging from mild to severe in terms of seizure type and severity. Seizures usually begin in infancy or early childhood (mean age at onset: 12.9 months, median: 10 months; range: 4-60 months; $\mathrm{n}=86$ patients from the literature and unpublished personal data) and are highly sensitive to fever. Febrile seizures (FS) are the initial manifestation in approximately half of the cases and seizures are triggered or worsened by fever in $\sim 90 \%$ of the patients [Scheffer et al., 2008; Depienne et al., 2009; Marini et al., 2010; Depienne et al., 2011]. Seizure types mostly consist in generalized tonic, clonic or tonic-clonic and/or focal seizures with or without secondary generalization. Atypical absences, atonic seizures and myoclonic jerks may also be part of the clinical picture, although they are more rarely observed [Scheffer et al., 2008; Depienne et al., 2009; Marini et al., 2010; Depienne et al., 2011; Specchio et al., 2011]. Status epilepticus, which can be inaugural, and prolonged seizures are frequently reported in $P C D H 19$-positive patients but the most characteristic feature is the presence of brief seizure clusters lasting 1-5 minutes and 
repeating up to or more than 10 times a day during several days [Depienne et al., 2009; Marini et al., 2010; Depienne et al., 2011; Specchio et al., 2011]. Seizures are resistant to treatment in most cases, especially during infancy and childhood, but their frequency and intractability tend to decrease naturally over time, some patients being sometimes free of seizures during adolescence or adulthood on monotherapy [Scheffer et al., 2008; Depienne et al., 2011; Specchio et al., 2011].

We and others have shown that the clinical spectrum associated with $P C D H 19$ mutations can overlap that of Dravet syndrome (DS, previously named severe myoclonic epilepsy of infancy or SMEI), a stereotyped epileptic encephalopathy also associating FS and epilepsy but due in $75 \%$ of cases to a de novo mutation in the SCN1A gene [Depienne et al., 2009; Marini et al., 2010; Depienne et al., 2011; Higurashi et al., 2011; Nabbout et al., 2011]. However, DS-like patients with $P C D H 19$ mutations slightly differ on average from SCN1A-positive classical DS patients: age at onset is slightly older (12.5 months [range: 4-60] versus 6.3 months [range: 0.5-14]), status epilepticus and occurrence of myoclonic jerks are less frequent, and long-term outcome is better in $P C D H 19$-positive patients than in SCN1A-positive patients, most patients with $P C D H 19$ mutations fitting the definition of bordeline SMEI (SMEB) [Fukuma et al., 2004]. Furthermore, photosensitivity, frequently reported in classical DS, is exceptional in PCDH19-positive patients [Depienne et al., 2009; Marini et al., 2010].

Behavioral disturbances are frequent in patients with heterozygous PCDH19 mutations and essentially manifest as autistic, obsessive or aggressive features [Scheffer et al., 2008; Depienne et al., 2009; Depienne et al., 2011; Marini et al., 2011]. In some patients, social withdrawal or personality disorders are even the most prominent and disabling feature when the patient becomes older [Depienne et al., 2011]. 
Intellectual outcome ranges from normal intellect $(27.7 \%, 23 / 83)$, to mild $(36.1 \%, 30 / 83)$, moderate $(21.7 \%, 18 / 83)$, or severe $(14.5 \%, 12 / 83)$ cognitive impairment [Scheffer et al., 2008; Depienne et al., 2009; Depienne et al., 2011; Marini et al., 2011; Specchio et al., 2011]. Interestingly, the cognitive prognosis does not appear to be clearly related to the severity of epilepsy [Depienne et al., 2011; Specchio et al., 2011]. Language delay is frequently associated with cognitive deficit.

Finally, neurological features such as ataxia can also be observed in some patients and are reminiscent of those observed in DS patients.

\section{Sporadic Versus Familial Cases}

Although $\mathrm{PCDH} 19$ was first identified in large families where the mutations were inherited over several generations, $\mathrm{PCDH} 19$-related epileptic encephalopathy is more commonly sporadic or encountered in families with few affected females, making the recognition of the unusual pattern of inheritance difficult. De novo mutations account for most isolated cases $(72 \%, 32 / 44)$ and represent $56 \%(32 / 57)$ of all mutations reported so far, in which transmission could be investigated [Depienne et al., 2009; Marini et al., 2010; Depienne et al., 2011; Specchio et al., 2011]. The remaining mutations found in sporadic cases were inherited by asymptomatic fathers $(18 \%, 8 / 44)$, asymptomatic mothers $(7 \%, 3 / 44)$ or by a mother who has had only FS (2\%). In addition, parental mosaicism leading to the recurrence of the disease was demonstrated in two mothers (one being asymptomatic and one being affected) of unrelated families [Dibbens et al., 2011], a result reminiscent of mosaicism in DS caused by SCN1A mutations [Depienne et al., 2010]. 


\section{Genotype-Phenotype Correlations}

Since the clinical features (age at onset, severity of the epilepsy and cognitive outcome) are highly variable for a given mutation even within the same family, genotype-phenotype correlation studies will likely be uninformative. Strikingly, Higurashi and collaborators reported monozygotic twin sisters in which the p.Asn340Ser mutation was associated with different clinical pictures, confirming the existence of non-genetic modifiers [Higurashi et al., 2011]. An expected source of phenotypic variability is the status of $\mathrm{X}$ inactivation in females. Interestingly, skewing of $\mathrm{X}$ chromosome inactivation can occur in normal females and increases in tissues with age [Chagnon et al., 2005; Bolduc et al., 2008]. A totally skewed X inactivation situation would theoretically reproduce a non-pathogenic situation. Partially skewed $\mathrm{X}$ inactivation would represent intermediate situations in which cellular interference could be limited compared to balanced $\mathrm{X}$ inactivation, where it would be expected to be the highest. In this setting, the severity of the epilepsy and/or the intellectual disability could be correlated with the relative amount of inactivated neurons for each chromosome, and the female mutation carriers with a totally skewed pattern of inactivation in the brain would be asymptomatic. However, so far no correlations between the $\mathrm{X}$-inactivation status in blood cells and the phenotypic expression have been found in support of this hypothesis [Marini et al., 2010]. Nonetheless, the X-inactivation status in lymphocytes does not reflect that of the neural tissues and studies investigating directly cerebral tissues, in mouse models for example, are important to further investigate this hypothesis.

\section{Diagnostic Relevance}

The identification of mutations of the PCDH19 gene provides a definite diagnosis in female patients with infantile epilepsy. This result also makes it possible to calculate the risk of 
recurrence of the disorder in the family, which is markedly different if the pathogenic mutation is de novo or if it has been inherited from a parent. Although diagnosis is made clinically, differentiating one epileptic condition from another is sometimes difficult, especially when the first symptoms appear. The molecular confirmation of the genetic defect underlying the epilepsy and an analysis of the parents' status are crucial to be able to give families appropriate genetic counseling.

Molecular testing of $\mathrm{PCDH} 19$ should be considered in females with early-onset FS and/or epilepsy with or without cognitive impairment and family history. Some clinical features could help to prioritize the analysis of $\mathrm{PCDH19}$, such as female patients presenting with seizure clusters, the presence of multiple affected females in the family with obligate male carriers, and, more generally, the presence of generalized and/or focal seizures beginning in infancy or early childhood, resistant to treatment and sensitive to fever. With regard to Dravet syndrome, screening for PCDH19 mutations should be performed for female patients when analysis of SCN1A is negative. Molecular testing of $P C D H 19$ should include sequencing of the coding sequence of the gene as well as a method (quantitative PCR, multiplex ligation-dependent probe amplification or equivalent) able to identify heterozygous deletions. The percentage of $P C D H 19$ positive cases in females with FS and epilepsy has been shown to range from 5 to $37 \%$ depending on the clinical criteria [Depienne et al., 2009; Marini et al., 2010; Depienne et al., 2011]. Molecular testing of PCDH19 in sporadic affected males can be considered with the same indication, although the somatic mosaicism expected in this case can easily be missed if the analysis is performed from genomic DNA extracted from blood cells, which considerably complicates the interpretation and decreases the reliability and significance of the result. 
Given the unusual mode of inheritance and the wide phenotypic variability associated with PCDH19 mutations, genetic counseling appears delicate. In the case of mutations inherited from an asymptomatic father, all the daughters are expected to be affected. Considering the frequent poor outcome (mild to severe cognitive impairment in about $70 \%$ of PCDH19-positive females) of $P C D H 19$-related epileptic encephalopathy, it is feasible to offer a prenatal diagnosis that could simply be based on fetal sex determination from maternal blood [Wright and Burton, 2009]. Female patients with PCDH19 mutations have a 50\% risk of transmitting the mutation but, as only the females would be affected, the overall risk would be $25 \%$. In cases with de novo mutations, the risk of recurrence is expected to be low but the possibility of germinal mosaicism in one parent is still possible [Dibbens et al., 2011]. 


\section{Future Prospects}

Although the frequency and clinical features of $P C D H 19$-related epileptic encephalopathies have become more precisely determined during the past 3 years, several challenges remain to fully understand the functional consequences of the mutations and the mechanisms by which they contribute to epileptogenesis and cognitive impairment.

Several steps were recently made towards elucidating the function of protocadherin 19 in zebrafish or chicken models. The zebrafish ortholog of protocadherin 19 (pcdh19) was shown to be crucial for early steps of brain morphogenesis. Partial depletion of the protein with morpholino oligonucleotides impairs the convergence cell movements of the anterior neural plate, where pcdh19 is specifically expressed, a phenotype reminiscent of the n-cadherin (ncad) mutants [Emond et al., 2009]. Interestingly, the Pcdh19 and Ncad proteins directly interact in vitro and in vivo in this model [Biswas et al., 2010]. Together with the observation that Pcdh19 exhibits weak homophilic adhesive properties [Biswas et al., 2010; Tai et al., 2010], these results suggest that protocadherin 19 could preferentially interact with other members of the cadherin superfamily to regulate cell adhesion, neuronal migration or synapse formation. The development of mouse models is an important step to confirm these hypotheses as well as the cellular interference theory, and to investigate the genetic or epigenetic factors underlying the phenotypic variability observed in the human disorder.

So far, although mammalian genomes contain over 70 protocadherin genes, only two, $P C D H 19$ and PCDH15 (causing autosomal recessive Usher syndrome) have been related to a human Mendelian disorder. Recent studies have suggested that defects in the expression or function of some other protocadherins may be related to neurodevelopmental disorders such as autism, schizophrenia and mental retardation [Bray et al., 2002; Dean et al., 2007; Morrow et al., 2008]. 
These findings suggest that protocadherins are likely to play many roles that have yet to be discovered in human disorders.

\section{Acknowledgments and fundings}

We thank the families for their participation, the clinicians who referred their patients to our laboratory, and the DNA and cell bank for DNA extraction and cell culture of research samples. The authors and their projects have been financially supported by GIS Maladies rares, Assistance Publique des hôpitaux de Paris (AP-HP) including the Programme Hospitalier de Recherche Clinique (PHRC) nP020910/AOR02085, Institut national de la santé et de la recherche médicale (INSERM), and Université Pierre et Marie-Curie (UPMC). The authors declare that they have no conflicts of interest and no financial interest in this study. 


\section{References}

Biswas S, Emond MR, Jontes JD. 2010. Protocadherin-19 and N-cadherin interact to control cell movements during anterior neurulation. J Cell Biol 191(5):1029-41.

Bolduc V, Chagnon P, Provost S, Dube MP, Belisle C, Gingras M, Mollica L, Busque L. 2008. No evidence that skewing of $\mathrm{X}$ chromosome inactivation patterns is transmitted to offspring in humans. J Clin Invest 118(1):333-41.

Bray NJ, Kirov G, Owen RJ, Jacobsen NJ, Georgieva L, Williams HJ, Norton N, Spurlock G, Jones S, Zammit S, O'Donovan MC, Owen MJ. 2002. Screening the human protocadherin 8 (PCDH8) gene in schizophrenia. Genes Brain Behav 1(3):187-91.

Chagnon P, Provost S, Belisle C, Bolduc V, Gingras M, Busque L. 2005. Age-associated skewing of $\mathrm{X}$-inactivation ratios of blood cells in normal females: a candidate-gene analysis approach. Exp Hematol 33(10):1209-14.

Compagni A, Logan M, Klein R, Adams RH. 2003. Control of skeletal patterning by ephrinB1EphB interactions. Dev Cell 5(2):217-30.

Dean B, Keriakous D, Scarr E, Thomas EA. 2007. Gene expression profiling in Brodmann's area 46 from subjects with schizophrenia. Aust N Z J Psychiatry 41(4):308-20.

Depienne C, Bouteiller D, Keren B, Cheuret E, Poirier K, Trouillard O, Benyahia B, Quelin C, Carpentier W, Julia S, Afenjar A, Gautier A, Rivier F, Meyer S, Berquin P, Helias M, Py I, Rivera S, Bahi-Buisson N, Gourfinkel-An I, Cazeneuve C, Ruberg M, Brice A, Nabbout R, Leguern E. 2009. Sporadic infantile epileptic encephalopathy caused by mutations in PCDH19 resembles Dravet syndrome but mainly affects females. PLoS Genet 5(2):e1000381. 
Depienne C, Trouillard O, Bouteiller D, Gourfinkel-An I, Poirier K, Rivier F, Berquin P, Nabbout R, Chaigne D, Steschenko D, Gautier A, Hoffman-Zacharska D, Lannuzel A, Lackmy-Port-Lis M, Maurey H, Dusser A, Bru M, Gilbert-Dussardier B, Roubertie A, Kaminska A, Whalen S, Mignot C, Baulac S, Lesca G, Arzimanoglou A, LeGuern E. 2011. Mutations and deletions in PCDH19 account for various familial or isolated epilepsies in females. Hum Mutat 32(1):E1959-75.

Depienne C, Trouillard O, Gourfinkel-An I, Saint-Martin C, Bouteiller D, Graber D, BarthezCarpentier MA, Gautier A, Villeneuve N, Dravet C, Livet MO, Rivier-Ringenbach C, Adam C, Dupont S, Baulac S, Heron D, Nabbout R, Leguern E. 2010. Mechanisms for variable expressivity of inherited SCN1A mutations causing Dravet syndrome. J Med Genet 47(6):404-10.

Dibbens LM, Kneen R, Bayly MA, Heron SE, Arsov T, Damiano JA, Desai T, Gibbs J, McKenzie F, Mulley JC, Ronan A, Scheffer IE. 2011. Recurrence risk of epilepsy and mental retardation in females due to parental mosaicism of PCDH19 mutations. Neurology 76(17):1514-9.

Dibbens LM, Tarpey PS, Hynes K, Bayly MA, Scheffer IE, Smith R, Bomar J, Sutton E, Vandeleur L, Shoubridge C, Edkins S, Turner SJ, Stevens C, O'Meara S, Tofts C, Barthorpe S, Buck G, Cole J, Halliday K, Jones D, Lee R, Madison M, Mironenko T, Varian J, West S, Widaa S, Wray P, Teague J, Dicks E, Butler A, Menzies A, Jenkinson A, Shepherd R, Gusella JF, Afawi Z, Mazarib A, Neufeld MY, Kivity S, Lev D, LermanSagie T, Korczyn AD, Derry CP, Sutherland GR, Friend K, Shaw M, Corbett M, Kim HG, Geschwind DH, Thomas P, Haan E, Ryan S, McKee S, Berkovic SF, Futreal PA, 
Stratton MR, Mulley JC, Gecz J. 2008. X-linked protocadherin 19 mutations cause female-limited epilepsy and cognitive impairment. Nat Genet 40(6):776-81.

Emond MR, Biswas S, Jontes JD. 2009. Protocadherin-19 is essential for early steps in brain morphogenesis. Dev Biol 334(1):72-83.

Fabisiak K, Erickson RP. 1990. A familial form of convulsive disorder with or without mental retardation limited to females: extension of a pedigree limits possible genetic mechanisms. Clin Genet 38(5):353-8.

Frank M, Kemler R. 2002. Protocadherins. Curr Opin Cell Biol 14(5):557-62.

Fukuma G, Oguni H, Shirasaka Y, Watanabe K, Miyajima T, Yasumoto S, Ohfu M, Inoue T, Watanachai A, Kira R, Matsuo M, Muranaka H, Sofue F, Zhang B, Kaneko S, Mitsudome A, Hirose S. 2004. Mutations of neuronal voltage-gated Na+ channel alpha 1 subunit gene SCN1A in core severe myoclonic epilepsy in infancy (SMEI) and in borderline SMEI (SMEB). Epilepsia 45(2):140-8.

Gaitan Y, Bouchard M. 2006. Expression of the delta-protocadherin gene Pcdh19 in the developing mouse embryo. Gene Expr Patterns 6(8):893-9.

Hertel N, Redies C. 2011. Absence of layer-specific cadherin expression profiles in the neocortex of the reeler mutant mouse. Cereb Cortex 21(5):1105-17.

Higurashi N, Shi X, Yasumoto S, Oguni H, Sakauchi M, Itomi K, Miyamoto A, Shiraishi H, Kato T, Makita Y, Hirose S. 2011. PCDH19 mutation in Japanese females with epilepsy. Epilepsy Res. In press.

Johnson WG. 1980. Metabolic interference and the + - heterozygote. a hypothetical form of simple inheritance which is neither dominant nor recessive. Am J Hum Genet 32(3):37486. 
Juberg RC, Hellman CD. 1971. A new familial form of convulsive disorder and mental retardation limited to females. J Pediatr 79(5):726-32.

Junghans D, Haas IG, Kemler R. 2005. Mammalian cadherins and protocadherins: about cell death, synapses and processing. Curr Opin Cell Biol 17(5):446-52.

Kim SY, Chung HS, Sun W, Kim H. 2007. Spatiotemporal expression pattern of non-clustered protocadherin family members in the developing rat brain. Neuroscience 147(4):9961021.

Kim SY, Mo JW, Han S, Choi SY, Han SB, Moon BH, Rhyu IJ, Sun W, Kim H. 2010. The expression of non-clustered protocadherins in adult rat hippocampal formation and the connecting brain regions. Neuroscience 170(1):189-99.

Klein R. 2004. Eph/ephrin signaling in morphogenesis, neural development and plasticity. Curr Opin Cell Biol 16(5):580-9.

Krishna K, Nuernberger M, Weth F, Redies C. 2009. Layer-specific expression of multiple cadherins in the developing visual cortex (V1) of the ferret. Cereb Cortex 19(2):388-401.

Krishna KK, Hertel N, Redies C. 2011. Cadherin expression in the somatosensory cortex: evidence for a combinatorial molecular code at the single-cell level. Neuroscience $175: 37-48$.

Marini C, Mei D, Parmeggiani L, Norci V, Calado E, Ferrari A, Moreira A, Pisano T, Specchio N, Vigevano F, Battaglia D, Guerrini R. 2010. Protocadherin 19 mutations in girls with infantile-onset epilepsy. Neurology 75(7):646-53.

Marini C, Scheffer IE, Nabbout R, Suls A, De Jonghe P, Zara F, Guerrini R. 2011. The genetics of Dravet syndrome. Epilepsia 52 Suppl 2:24-9. 
Morishita H, Yagi T. 2007. Protocadherin family: diversity, structure, and function. Curr Opin Cell Biol 19(5):584-92.

Morrow EM, Yoo SY, Flavell SW, Kim TK, Lin Y, Hill RS, Mukaddes NM, Balkhy S, Gascon G, Hashmi A, Al-Saad S, Ware J, Joseph RM, Greenblatt R, Gleason D, Ertelt JA, Apse KA, Bodell A, Partlow JN, Barry B, Yao H, Markianos K, Ferland RJ, Greenberg ME, Walsh CA. 2008. Identifying autism loci and genes by tracing recent shared ancestry. Science 321(5886):218-23.

Nabbout R, Depienne C, Chiron C, Dulac O. 2011. Protocadherin 19 mutations in girls with infantile-onset epilepsy. Neurology 76(13):1193-4; author reply 1194.

Patel SD, Chen CP, Bahna F, Honig B, Shapiro L. 2003. Cadherin-mediated cell-cell adhesion: sticking together as a family. Curr Opin Struct Biol 13(6):690-8.

Patel SD, Ciatto C, Chen CP, Bahna F, Rajebhosale M, Arkus N, Schieren I, Jessell TM, Honig B, Price SR, Shapiro L. 2006. Type II cadherin ectodomain structures: implications for classical cadherin specificity. Cell 124(6):1255-68.

Redies C, Vanhalst K, Roy F. 2005. delta-Protocadherins: unique structures and functions. Cell Mol Life Sci 62(23):2840-52.

Ryan SG, Chance PF, Zou CH, Spinner NB, Golden JA, Smietana S. 1997. Epilepsy and mental retardation limited to females: an X-linked dominant disorder with male sparing. Nat Genet 17(1):92-5.

Scheffer IE, Turner SJ, Dibbens LM, Bayly MA, Friend K, Hodgson B, Burrows L, Shaw M, Wei C, Ullmann R, Ropers HH, Szepetowski P, Haan E, Mazarib A, Afawi Z, Neufeld MY, Andrews PI, Wallace G, Kivity S, Lev D, Lerman-Sagie T, Derry CP, Korczyn AD, 
Gecz J, Mulley JC, Berkovic SF. 2008. Epilepsy and mental retardation limited to females: an under-recognized disorder. Brain 131(Pt 4):918-27.

Specchio N, Marini C, Terracciano A, Mei D, Trivisano M, Sicca F, Fusco L, Cusmai R, Darra F, Bernardina BD, Bertini E, Guerrini R, Vigevano F. 2011. Spectrum of phenotypes in female patients with epilepsy due to protocadherin 19 mutations. Epilepsia.

Tai K, Kubota M, Shiono K, Tokutsu H, Suzuki ST. 2010. Adhesion properties and retinofugal expression of chicken protocadherin-19. Brain Res 1344:13-24.

Tarpey PS, Smith R, Pleasance E, Whibley A, Edkins S, Hardy C, O'Meara S, Latimer C, Dicks E, Menzies A, Stephens P, Blow M, Greenman C, Xue Y, Tyler-Smith C, Thompson D, Gray K, Andrews J, Barthorpe S, Buck G, Cole J, Dunmore R, Jones D, Maddison M, Mironenko T, Turner R, Turrell K, Varian J, West S, Widaa S, Wray P, Teague J, Butler A, Jenkinson A, Jia M, Richardson D, Shepherd R, Wooster R, Tejada MI, Martinez F, Carvill G, Goliath R, de Brouwer AP, van Bokhoven H, Van Esch H, Chelly J, Raynaud M, Ropers HH, Abidi FE, Srivastava AK, Cox J, Luo Y, Mallya U, Moon J, Parnau J, Mohammed S, Tolmie JL, Shoubridge C, Corbett M, Gardner A, Haan E, Rujirabanjerd S, Shaw M, Vandeleur L, Fullston T, Easton DF, Boyle J, Partington M, Hackett A, Field M, Skinner C, Stevenson RE, Bobrow M, Turner G, Schwartz CE, Gecz J, Raymond FL, Futreal PA, Stratton MR. 2009. A systematic, large-scale resequencing screen of Xchromosome coding exons in mental retardation. Nat Genet 41(5):535-43.

Vanhalst K, Kools P, Staes K, van Roy F, Redies C. 2005. delta-Protocadherins: a gene family expressed differentially in the mouse brain. Cell Mol Life Sci 62(11):1247-59. 
Vincent AK, Noor A, Janson A, Minassian BA, Ayub M, Vincent JB, Morel CF. 2011.

Identification of genomic deletions spanning the PCDH19 gene in two unrelated girls with intellectual disability and seizures. Clin Genet. In press.

Wieland I, Jakubiczka S, Muschke P, Cohen M, Thiele H, Gerlach KL, Adams RH, Wieacker P. 2004. Mutations of the ephrin-B1 gene cause craniofrontonasal syndrome. Am J Hum Genet 74(6):1209-15.

Wolverton T, Lalande M. 2001. Identification and characterization of three members of a novel subclass of protocadherins. Genomics 76(1-3):66-72.

Wright CF, Burton H. 2009. The use of cell-free fetal nucleic acids in maternal blood for noninvasive prenatal diagnosis. Hum Reprod Update 15(1):139-51.

Yagi T, Takeichi M. 2000. Cadherin superfamily genes: functions, genomic organization, and neurologic diversity. Genes Dev 14(10):1169-80. 


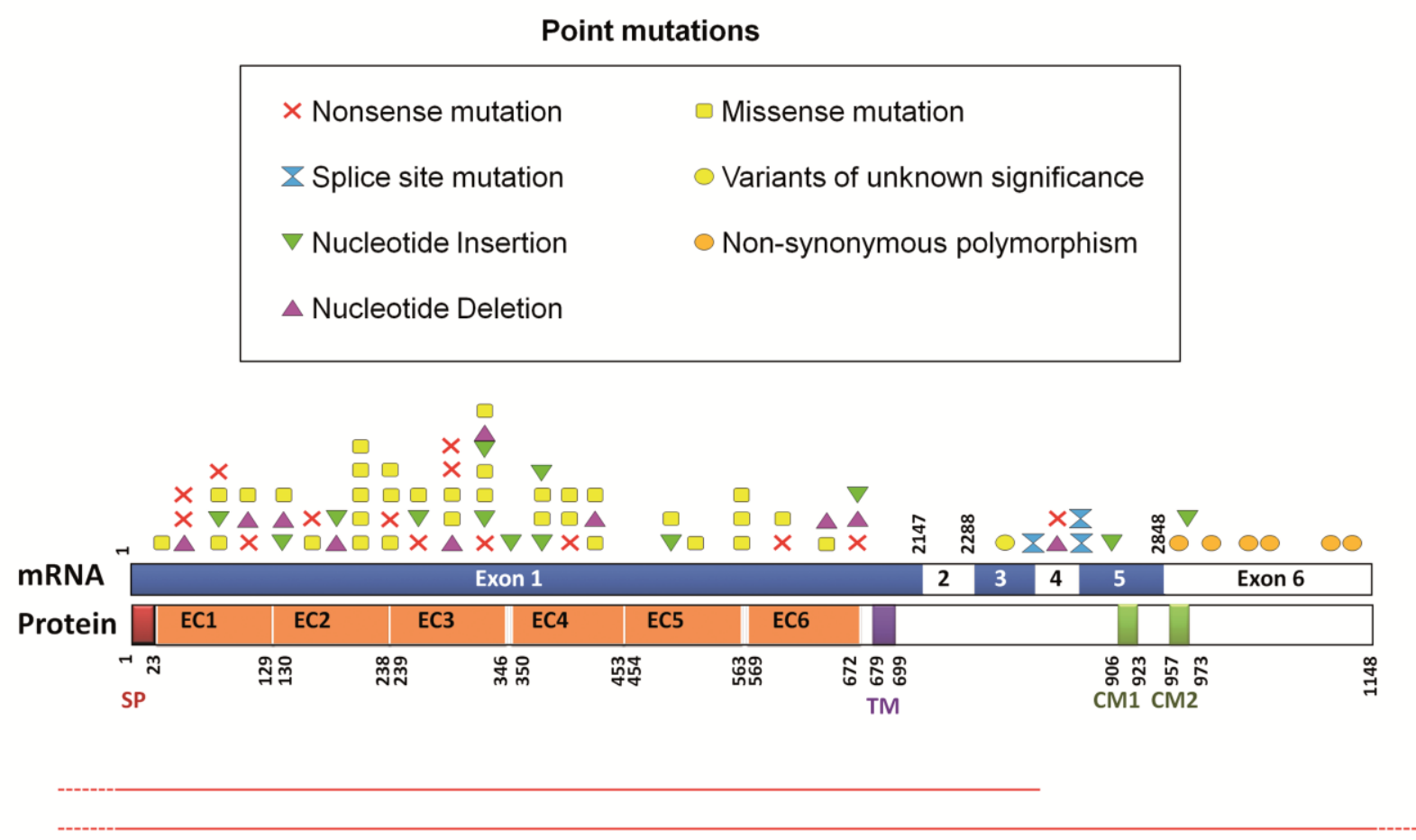

Microdeletions

Figure 1. Schematic representation of the mutations, rearrangements and polymorphisms identified in the PCDH19 gene on the mRNA and protein. Point mutations (above): red crosses, nonsense mutations; yellow squares, missense mutations; hourglass, splice site mutations; green/pink triangles, small insertions/deletions leading to a frameshift; orange circles, non-synonymous polymorphisms; yellow circles, variants of unknown significance. Microrearrangements (below): red lines indicate deletions. Dashed lines indicate that the deletion continues farther than the gene. 
TABLE 1A. Pathogenic mutations identified in the $P C D H 19$ Gene

\begin{tabular}{|c|c|c|c|c|c|c|}
\hline $\begin{array}{l}\text { Exon / } \\
\text { intron }\end{array}$ & DNA variant & $\begin{array}{l}\text { Predicted effect on the } \\
\text { protein }\end{array}$ & Type & $\begin{array}{c}\text { Recurrent } \\
\text { mutation }\end{array}$ & Transmission & References \\
\hline Exon 1 & c.74T>C & p.Leu25Pro & Missense & & Mosaic mother & Dibbens et al. 2011 \\
\hline Exon 1 & c.78delG & p.Lys26AsnfsX4 & Frameshift & & De Novo & Jamal et al., 2010 \\
\hline Exon 1 & {$[c .83 \mathrm{C}>\mathrm{A} ; \mathrm{c} .90 \mathrm{~A}>\mathrm{G}]$} & p.Ser28X & Nonsense & & De Novo & Marini et al., 2010 \\
\hline Exon 1 & c. $142 \mathrm{G}>\mathrm{T}$ & p.Glu48X & Nonsense & & Paternal inheritance & Depienne et al., 2009 \\
\hline Exon 1 & c.215T>G & p.Val72Gly & Missense & & Unknown & Higurashi et al., 2011 \\
\hline Exon 1 & c.241dupC & p.Leu81ProfsX8 & Frameshift & & De Novo & This study \\
\hline Exon 1 & c. $242 T>G$ & p.Leu81Arg & Missense & & Unknown & Depienne et al., 2011 \\
\hline Exon 1 & c. $253 C>T$ & p.GIn85X & Nonsense & yes & Familial condition & Dibbens et al., 2008, this study \\
\hline Exon 1 & c. $352 \mathrm{G}>\mathrm{T}$ & p.Glu118X & Nonsense & & De Novo & Depienne et al., 2009; this study \\
\hline Exon 1 & c.357delC & p.Lys120ArgfsX3 & Frameshift & & Familial condition & Dibbens et al., 2008 \\
\hline Exon 1 & c. $361 \mathrm{G}>\mathrm{A}$ & p.Asp121Asn & Missense & & Paternal inheritance & Depienne et al., 2009 \\
\hline Exon 1 & c.415_423dup & p.Ser139_Ala141dup & $\begin{array}{l}\text { In-frame } \\
\text { duplication }\end{array}$ & & Maternal inheritance & Depienne et al., 2011 \\
\hline Exon 1 & c.424delG & p.Ala142ProfsX70 & Frameshift & & Unknown & Depienne et al., 2011 \\
\hline
\end{tabular}




\begin{tabular}{|c|c|c|c|c|c|}
\hline Exon 1 & c. $437 \mathrm{C}>\mathrm{G}$ & p.Thr146Arg & Missense & Paternal inheritance & Depienne et al., 2011 \\
\hline Exon 1 & c. $457 \mathrm{G}>\mathrm{A}$ & p.Ala153Thr & Missense & Paternal inheritance & This study \\
\hline Exon 1 & c. $462 \mathrm{C}>\mathrm{A}$ & p.Tyr154X & Nonsense & Unknown & Depienne et al., 2011 \\
\hline Exon 1 & c.506delC & p.Thr169SerfsX43 & Frameshift & De Novo & Depienne et al., 2009 \\
\hline Exon 1 & c.514dupG & p.Glu172GlyfsX54 & Frameshift & $\begin{array}{l}\text { Unknown (not in the } \\
\text { mother) }\end{array}$ & Depienne et al., 2011 \\
\hline Exon 1 & c.569T>G & p.Leu190Arg & Missense & Unknown & This study \\
\hline Exon 1 & c. $571 \mathrm{G}>\mathrm{C}$ & p.Val191Leu & Missense & Unknown & Higurashi et al., 2011 \\
\hline Exon 1 & c. $595 \mathrm{G}>\mathrm{C}$ & p.Glu199GIn & Missense & $\begin{array}{l}\text { Unknown (not in the } \\
\text { mother) }\end{array}$ & Depienne et al., 2009 \\
\hline Exon 1 & {$[\mathrm{c} .608 \mathrm{~A}>\mathrm{C} ; \mathrm{c} .617 \mathrm{~T}>\mathrm{G}]$} & [p.His203Pro; Phe206Cys] & Missense & De Novo & Marini et al., 2010 \\
\hline Exon 1 & c. $617 \mathrm{~T}>\mathrm{A}$ & p.Phe206Tyr & Missense & $\begin{array}{c}\text { Maternal inheritance } \\
\text { (mother asymptomatic) }\end{array}$ & Depienne et al., 2011 \\
\hline Exon 1 & c. $695 \mathrm{~A}>\mathrm{G}$ & p.Asn232Ser & Missense & Unknown & This study \\
\hline Exon 1 & c.697_700delinsTAAC & p.Asp233X & Nonsense & $\begin{array}{l}\text { Unknown (not in the } \\
\text { mother) }\end{array}$ & Depienne et al., 2011 \\
\hline Exon 1 & c. $701 \mathrm{~A}>\mathrm{G}$ & p.Asn234Ser & \begin{tabular}{|l|} 
Missense \\
\end{tabular} & De Novo & This study \\
\hline Exon 1 & c.706C>T & p.Pro236Ser & Missense & De Novo & Specchio et al., 2011 \\
\hline Exon 1 & c. $729 \mathrm{C}>\mathrm{A}$ & p.Tyr243X & Nonsense & De Novo & Jamal et al., 2010 \\
\hline
\end{tabular}




\begin{tabular}{|c|c|c|c|c|c|c|}
\hline Exon 1 & c.730dupG & p.Ala244GlyfsX76 & Frameshift & & De Novo & This study \\
\hline Exon 1 & c. $747 \mathrm{~A}>\mathrm{T}$ & p.Glu249Asp & Missense & & $\begin{array}{l}\text { Maternal inheritance } \\
\text { (mother with FS) }\end{array}$ & Depienne et al., 2011 \\
\hline Exon 1 & c.772_773delAT & p.lle258ProfsX61 & Frameshift & & Unknown & Higurashi et al., 2011 \\
\hline Exon 1 & c. $785 \mathrm{C}>\mathrm{A}$ & p.Ala262Asp & Missense & & Unknown & This study \\
\hline Exon 1 & c.826T>C & p.Ser276Pro & Missense & & De Novo & Hynes et al., 2010 \\
\hline Exon 1 & c. $840 \mathrm{C}>\mathrm{G}$ & p.Tyr280X & Nonsense & & De Novo & Higurashi et al., 2011 \\
\hline Exon 1 & c. $859 \mathrm{G}>\mathrm{T}$ & p.Glu287X & Nonsense & yes & $\begin{array}{l}\text { De novo }(\mathrm{n}=1) ; \text { unknown } \\
(\mathrm{n}=1)\end{array}$ & Depienne et al., 2009 \\
\hline Exon 1 & c.949C>T & p.GIn317X & Nonsense & & Familial condition & Higurashi et al., 2011 \\
\hline Exon 1 & c.958dupG & p.Asp320GlyfsX22 & Frameshift & & De Novo & Specchio et al., 2011 \\
\hline Exon 1 & c. $1019 A>G$ & p.Asn340Ser & Missense & yes & $\begin{array}{l}\text { De Novo }(n=7) ; \text { inherited } \\
\text { from the mother }(n=1) \\
\text { mosaic mother }(n=1) ; \\
\text { unknown }(n=1)\end{array}$ & $\begin{array}{l}\text { Depienne et al., 2009; Marini et } \\
\quad \text { al., 2010; Specchio et al., } \\
\text { 2011;Dibbens et al. 2011; } \\
\text { Higurashi et al., } 2011 \text {; this study }\end{array}$ \\
\hline Exon 1 & c. $1023 C>G$ & p.Asp341Glu & Missense & & De Novo & Depienne et al., 2011 \\
\hline Exon 1 & c.1026_1027delinsAA & p.Asn342_Pro343delinsLysThr & Frameshift & & Unknown & This study \\
\hline Exon 1 & c. $1031 C>G$ & p.Pro344Arg & Missense & & Unknown & This study \\
\hline Exon 1 & c.1036_1040dup & p.Asn347LysfsX23 & Frameshift & & Familial condition & Depienne et al., 2009 \\
\hline Exon 1 & c.1091dupC & p.Tyr366LeufsX10 & Frameshift & yes & $\begin{array}{l}\text { De Novo }(n=1) \text {; familial } \\
\text { condition }(n=1) ; \text { Paternal }\end{array}$ & $\begin{array}{l}\text { Dibbens et al., 2008; Higurashi et } \\
\text { al., 2011; this study }\end{array}$ \\
\hline
\end{tabular}




\begin{tabular}{|c|c|c|c|c|c|c|}
\hline & & & & & inheritance $(n=1)$ & \\
\hline Exon 1 & c. $1129 \mathrm{G}>\mathrm{C}$ & p.Asp377His & Missense & & De Novo & Marini et al., 2010 \\
\hline Exon 1 & c. $1131 \mathrm{C}>\mathrm{A}$ & p.Asp377Glu & Missense & & De Novo & This study \\
\hline Exon 1 & c.1143dupT & p.Gly382TrpfsX19 & Frameshift & & Unknown & This study \\
\hline Exon 1 & c. $1192 \mathrm{G}>\mathrm{T}$ & p.Glu398X & Nonsense & & Paternal inheritance & Marini et al., 2010 \\
\hline Exon 1 & c. $1211 \mathrm{C}>\mathrm{T}$ & p.Thr404lle & Missense & & De Novo & Marini et al., 2010 \\
\hline Exon 1 & c. $1240 \mathrm{G}>\mathrm{C}$ & p.Glu414Gln & Missense & & Paternal inheritance & Marini et al., 2010 \\
\hline Exon 1 & c. $1298 \mathrm{~T}>\mathrm{C}$ & p.Leu433Pro & Missense & & De Novo & Specchio et al., 2011 \\
\hline Exon 1 & c.1300_1301delCA & p.GIn434GlufsX11 & Frameshift & & De Novo & Specchio et al., 2011 \\
\hline Exon 1 & c. $1322 \mathrm{~T}>\mathrm{A}$ & p.Val441Glu & Missense & & Familial condition & Dibbens et al., 2008 \\
\hline Exon 1 & c.1521dupC & p.Ile508HisfsX15 & Frameshift & & Unknown & Marini et al., 2010 \\
\hline Exon 1 & c. $1537 G>C$ & p.Gly513Arg & Missense & & De Novo & Specchio et al., 2011 \\
\hline Exon1 & c. $1628 \mathrm{~T}>\mathrm{C}$ & p.Leu543Pro & Missense & & Paternal inheritance & Depienne et al., 2009 \\
\hline Exon 1 & c. $1671 C>G$ & P.Asn557Lys & Missense & & Familial condition & $\begin{array}{l}\text { Dibbens et al., 2008; Hynes et } \\
\text { al., } 2010\end{array}$ \\
\hline Exon 1 & c. $1682 C>G$ & p.Pro561Arg & Missense & yes & $\begin{array}{c}\text { Paternal inheritance }(n=1), \\
\text { unknown }(n=1)\end{array}$ & Depienne et al., 2011 \\
\hline Exon 1 & c. $1700 \mathrm{C}>\mathrm{T}$ & p.Pro567Leu & Missense & & $\begin{array}{c}\text { Maternal inheritance } \\
\text { (mother asymptomatic) }\end{array}$ & Depienne et al., 2011 \\
\hline
\end{tabular}




\begin{tabular}{|c|c|c|c|c|c|c|}
\hline Exon 1 & c. $1804 \mathrm{C}>\mathrm{T}$ & p.Arg602X & Nonsense & & De Novo & This study \\
\hline Exon 1 & c. $1852 \mathrm{G}>\mathrm{A}$ & p.Asp618Asn & Missense & & $\begin{array}{c}\text { Maternal inheritance } \\
\text { (mother asymptomatic) }\end{array}$ & Depienne et al., 2011 \\
\hline Exon 1 & c. $1924 \mathrm{G}>\mathrm{A}$ & p.Val642Met & Missense & & Unknown & This study \\
\hline Exon 1 & C.1956_1959delCTCT & p.Ser653ProfsX6 & Frameshift & & Unknown & This study \\
\hline Exon 1 & c. $2012 C>G$ & p.Ser671X & Nonsense & & Familial condition & Dibbens et al., 2008 \\
\hline Exon 1 & c.2019delC & p.Ser674LeufsX2 & Frameshift & & De Novo & Depienne et al., 2011 \\
\hline Exon 1 & c.2030dupT & p.Leu677PhefsX41 & Frameshift & & Familial condition & Dibbens et al., 2008 \\
\hline Intron 3 & c. $2617-1 \mathrm{G}>\mathrm{A}$ & p.? & $\begin{array}{l}\text { Misplicing } \\
\text { (abolition of exon } \\
4 \text { acceptor site) }\end{array}$ & & De Novo & Marini et al., 2010 \\
\hline Exon 4 & c.2631_2634delTTTT & p.Phe878ThrfsX5 & Frameshift & & De Novo & Jamal et al., 2010 \\
\hline Exon 4 & c. 2656 C>T & p.Arg886X & Nonsense & yes & $\begin{array}{l}\text { Familial condition } \\
(n=1) ; \text { unknown }(n=1)\end{array}$ & Depienne et al., 2011; this study \\
\hline Intron 4 & c. $2675+1 \mathrm{G}>\mathrm{C}$ & p.? & Misplicing & & $\begin{array}{l}\text { Unknown (not in the } \\
\text { mother) }\end{array}$ & This study \\
\hline Intron 4 & c. $2676-6 A>G$ & p.? & $\begin{array}{l}\text { Misplicing } \\
\text { (creation of a new } \\
\text { acceptor site) }\end{array}$ & & De Novo & Marini et al., 2010 \\
\hline Exon 6 & c.2697dupA & p.Glu900ArgfsX8 & Frameshift & & De Novo & Marini et al., 2010 \\
\hline Exon 6 & c.2903dupA & p.Asp968GlufsX18 & Frameshift & & De Novo & Marini et al., 2010 \\
\hline
\end{tabular}


Mutation nomenclature is based on the PCDH19 cDNA reference sequence (NM_001184880.1). Nucleotide numbering reflects cDNA numbering with +1 corresponding to the A of the ATG translation initiation codon in the reference sequence.

TABLE 1B. Variant in $P C D H 19$ of unknown significance (possibly pathogenic)

\begin{tabular}{c|c|c|c|c|c|c|}
\hline $\begin{array}{c}\text { Exon / } \\
\text { intron }\end{array}$ & DNA variant & $\begin{array}{c}\text { Predicted effect on the } \\
\text { protein }\end{array}$ & Type & $\begin{array}{c}\text { Phenotype of the } \\
\text { patient (gender) }\end{array}$ & Transmission & References \\
\hline Exon 3 & c.2454C>G & p.His817Gln & Missense & $\begin{array}{c}\text { Mental retardation } \\
\text { (unknown) }\end{array}$ & Unknown & Tarpey et al., 2009 \\
\hline
\end{tabular}

Mutation nomenclature is based on the PCDH19 cDNA reference sequence (NM_001184880.1). Nucleotide numbering reflects cDNA numbering with +1 corresponding to the A of the ATG translation initiation codon in the reference sequence.

TABLE 1C. Pathogenic rearrangements identified in the PCDH19 Gene

\begin{tabular}{|c|c|c|c|c|c|c|}
\hline $\begin{array}{l}\text { Exon / } \\
\text { intron }\end{array}$ & DNA variant & $\begin{array}{l}\text { Predicted effect on the } \\
\text { protein }\end{array}$ & Type & $\begin{array}{l}\text { Recurrent } \\
\text { mutation }\end{array}$ & Transmission & References \\
\hline Exons 1-6 & c.1-?_3447+?del & Absence of protein synthesis & $\begin{array}{l}\text { Whole gene } \\
\text { deletion }\end{array}$ & $\begin{array}{l}\text { recurrent gene del } \\
\text { with different BP }\end{array}$ & $\begin{array}{l}\text { De Novo }(\mathrm{n}=3) ; \text { unknown } \\
(\mathrm{n}=2)\end{array}$ & $\begin{array}{l}\text { Depienne et al., 2009; Depienne } \\
\text { et al., } 2011 \text {; Vincent et al., } 2011\end{array}$ \\
\hline Exons 1-3 & c.1-?_2616+?del & Absence of protein synthesis & $\begin{array}{l}\text { Deletion of exons } \\
1,2 \text { and } 3\end{array}$ & & De Novo & Depienne et al., 2011 \\
\hline
\end{tabular}

BP: breakpoints 
TABLE 2. Frequent and rare polymorphisms of the $P C D H 19$ Gene

\begin{tabular}{|c|c|c|c|c|c|}
\hline Ex/intr & Nucleotide change & $\begin{array}{l}\text { Protein } \\
\text { consequence }\end{array}$ & rs number & $\begin{array}{c}\text { Frequency } \\
\text { in European population } \\
\text { (other populations) }\end{array}$ & Ref \\
\hline Exon1 & c. $6 \mathrm{G}>\mathrm{A}$ & p.Glu2Glu & & $<2 \%$ & $\begin{array}{c}\text { Hynes et al., } 2010 ; \text {; Higurashi et al., } \\
2011\end{array}$ \\
\hline Exon1 & c. $402 \mathrm{C}>\mathrm{A}$ & p.lle134lle & rs41300169 & $7 \%$ & $\begin{array}{l}\text { Hynes et al., 2010; Depienne et al., } \\
2011 \text {; Higurashi et al., } 2011\end{array}$ \\
\hline Exon1 & c.531G $>A$ & p.Glu177Glu & & $<1 \%$ (Japan population) & Higurashi et al., 2011 \\
\hline Exon1 & c. $655 \mathrm{C}>\mathrm{T}$ & p.Leu219Leu & & $<1 \%$ & Hynes et al., 2010 \\
\hline Exon1 & c. $1137 \mathrm{C}>\mathrm{T}$ & p.Gly379Gly & rs56277715 & $4 \%$ & $\begin{array}{l}\text { Hynes et al., 2010; Depienne et al., } \\
\qquad 2011\end{array}$ \\
\hline Exon1 & c. $1627 \mathrm{C}>\mathrm{T}$ & p.Leu543Leu & & $20 \%$ & $\begin{array}{l}\text { Tarpey et al., 2009; Hynes et al., 2010; } \\
\text { Depienne et al., } 2011\end{array}$ \\
\hline Exon1 & c. $1683 G>A$ & p.Pro561Pro & & $<1 \%$ & Tarpey et al., 2009; Hynes et al., 2010 \\
\hline Intron 3 & c. $2617-27 \mathrm{C}>\mathrm{A}$ & & & & This study \\
\hline Intron 5 & c. $2849-28 \mathrm{~A}>\mathrm{C}$ & & & & This study \\
\hline Exon6 & c. $2873 G>A$ & p.Arg958Gln & & $<1 \%$ & Tarpey et al., 2009; Hynes et al., 2010 \\
\hline Exon6 & c. $2938 \mathrm{C}>\mathrm{T}$ & p.Arg980Cys & rs3764758 & $<1 \%$ (Asian population) & $\begin{array}{l}\text { Hapmap data (phase II) ; Higurashi et } \\
\text { al., } 2011\end{array}$ \\
\hline Exon6 & c. $2994 \mathrm{~T}>\mathrm{C}$ & p.Thr998Thr & & $<1 \%$ (Japan population) & Higurashi et al., 2011 \\
\hline
\end{tabular}




\begin{tabular}{|c|c|c|c|c|c|}
\hline Exon6 & c. $3018 \mathrm{C}>\mathrm{T}$ & p.Asp1006Asp & rs16983426 & $\begin{array}{c}<1 \% \text { (17\%African } \\
\text { population) }\end{array}$ & Tarpey et al., 2009; dbSNP \\
\hline Exon6 & c.3280C>G & p.Leu1094Val & & $<1 \%$ & This study ; Higurashi et al., 2011 \\
\hline Exon 6 & c. $3319 C>G$ & p.Arg1107Gly & & $\begin{array}{c}\text { 1- } \\
\begin{array}{c}(2-3 \% \text { in Japan } \\
\text { population })\end{array}\end{array}$ & Depienne et al., 2009 \\
\hline Exon 6 & c. $3400 A>C$ & p.Asn1134His & & $\begin{array}{c}<1 \% \text { ( }>10 \% \text { in Japan } \\
\text { population) }\end{array}$ & This study; Higurashi et al., 2011 \\
\hline 3'UTR & c. $3447+8 \mathrm{~T}>\mathrm{C}$ & & & $<1 \%$ & This study \\
\hline
\end{tabular}

Mutation nomenclature is based on the PCDH19 cDNA reference sequence (NM_001184880.1). Nucleotide numbering reflects cDNA numbering with +1 corresponding to the $A$ of the ATG translation initiation codon in the reference sequence. 